\title{
Moral Hazard in IT Project Completion. A MultipleStudy Analysis Case
}

\author{
Bartosz Wachnik \\ Warsaw University of Technology, \\ Faculty of Production Engineering \\ Institute of Organization of \\ Production Systems \\ ul. Narbutta 85, 02-524 Warszawa, \\ Poland \\ Email: bartek@wachnik.eu
}

\begin{abstract}
Implementing management support information systems with the use of outsourcing is the prevalent method of completing this type of project in Poland. Agency theory is one of the significant categories of theories used in the analysis of IT outsourcing. Literature studies indicate a research gap concerning the phenomenon of moral hazard in IT projects consisting in the implementation of management support information systems. The scope of this article is to present research results on the phenomenon of moral hazard based on the case study method. The research results may be interesting for theoreticians of business informatics and for practitioners completing IT projects both in enterprises and government agencies.
\end{abstract}

\section{INTRODUCTION}

A CCORDING to J. Lee [1], IT outsourcing means managing a company's IT infrastructure through administration mechanisms exercised in cooperation with external organizations. A particularly interesting area of IT outsourcing is the purchase of implementation services as part of the completion of IT projects consisting in management information system implementation. The author's research has shown that IT outsourcing linked directly to the implementation of management support information systems, i.e. ERP, BI, CRM and DMS, was used in $78 \%$ of Polish enterprises, while the remaining $22 \%$ completed this type of project themselves. ${ }^{1}$ Consequently, the issue of outsourcing in this type of project is clearly visible in the majority of Polish companies and it requires further research by theoreticians of business informatics in Poland. Internationally, issues linked to IT outsourcing have been the subject of research by business informatics theoreticians for many years. J. Dibbern [2] analyzed 84 articles on IT outsourcing published between 1992 and 2000. 10 categories of theories used to analyze the question of IT outsourcing were identified, which were then divided into three groups: strategies, economy and social-organizational groups. Agency theory was ranked third in terms

The research was carried out between 2012 and 2014 amongst 300 companies based in Mazovia, Greater and Lesser Poland, as well as Upper and Lower Silesia, which completed 370 projects consisting in management support information system implementation. The selected enterprises met the following criteria: number of employees between 80 and 1000, own IT department, minimal income: 40mln PLN. of the number of publications, ${ }^{2}$ which shows that it is frequently used in research on IT outsourcing. Agency theory stems from the need to explain the behavior of participants in relations client-contractor, where both parties have different goals. The risk is known as agency problem, relations - as contract, and the parties of the relation - as principal and agent. Agency theory addresses the phenomenon of dependency, where the principal delegates tasks to the agent. Agency problem is considered in two aspects [3]. First, it refers to the contradictory goals of both parties, which result in different expectations dependent on classifying the risk priority differently - the so-called risk preferences, linked to the agent's activities carried out on the principals' orders. Both sides of the relation try to minimize the risk. Different goals may result from opportunism, where both sides enforce the realization of their own goals over common goals. The second problem refers to the mechanism which influences specific behaviors of the agent, according to the principal's expectations [4]. The unit which constitutes the basis of theory analysis is the contract defining the rules of cooperation between the principal and the agent. Important concepts introduced by the theory are: moral hazard, adverse selection and programmability. According to the research carried out by Dembe and Boden [5], the term "moral hazard" dates back to the 18th century and was widely used by British insurance companies until the end of the 19th century. The early usage of the term has negative connotations, linked to fraud or other immoral behavior - usually on the insuree's part. Renewed scientific interest in the phenomenon of moral hazard appeared amongst economists in the 1960s, and it was not applied to instances of fraud or immoral behavior. The term would be used to describe ineffectiveness, which could

${ }^{2}$ The ranking of theories applied to research of IT outsourcing with the use of 84 articles conducted by J. Dibbern, T. Goles, R. Hirscheim and B. Jayatilaka [2]. Theory of transaction costs-16, Strategic management theory-14, Agency theory-10, Group of resource allocation theories-9, Group of social exchange theories - 7, Game theory-4, Theory of power group - 2, Diffusion of innovations theory-2, Other theories, e.g. of knowledge management, risk management, psychological contract -13 . 
appear in case of bad risk management, rather than in the context of ethics.

We need to stress here that the agency theory, alongside institutionalism, the theory of contracts and the theory of transaction costs, constitutes a component of the new institutional economy [6], which is based on the idea of institution understood in three categories: $A$. social, defining the norms of human relations, $B$. legal, regulating the creation, duration and termination of legal relationship between legal entities and $C$. organizational, regulating the functioning of formal organizations, safeguarding certain norms.

J. M. Buchanan [7] confirmed that a new contractarian paradigm of a new institutional economy is forming, which he described by saying that "economics comes closer to being a 'science of contract' than a 'science of choice' [...] The maximizer must be replaced by the arbitrator, the outsider who tries to work out compromises among conflicting claims." This statement, as well as the concept of treating an enterprise as a cluster of contracts and making the project's success dependent upon the quality of contracts, fully confirm the rationale of a new institutional economy as a central element creating a model of IT services in the form of outsourcing.

The scope of the article is to present research results concerning the incidence of moral hazard in IT project completion as part of outsourcing. In the article, I focus on projects consisting in the implementation of management support information systems, i.e. ERP, BI, CRM and DMS. The article stems from an attempt to identify the conditions influencing the effectiveness of completing a given group of IT projects based on outsourcing. In my opinion, the factors influencing the effectiveness of IT project completion have been changing over the years and their character has become increasingly nuanced. This results from many factors, i.e. the rapidly changing technology, the evolution of project completion methods, the fast-growing saturation of IT system markets, the hypercompetition amongst suppliers, the behaviors and practices of suppliers during the process of sale or project completion. This is why I believe that researching the problem of outsourcing in IT projects is important, where the results will be beneficial both for theoreticians of business informatics and practitioners working in companies and government agendas. The article belongs to a cycle of over a dozen articles that I wrote to present the results of my research on IT project completion as part of outsourcing.

\section{MORAL HAZARD IN IT PROJECT COMPLETION}

According to Y. Lichtenstein [8], agency theory describes the methods of completing IT projects during the whole life cycle of a project, i.e. as part of the following three stages:
Stage 1-Organization and completion of a tender aimed at selecting a management support information system and a company to implement it.

Stage 2-IT project completion.

Stage 3-Information system operation on the basis of an SLA contract.

Agency theory presents the contract for the service of implementation of a management support information system between the supplier and the customer as a relation between an agent and a principal. During the first stage of a project's life, an outsourcing agreement for the provision of IT system implementation services is established, and later on a Service Level Agreement is negotiated. Y. Lichtenstein [8] indicates that in case of negotiating IT project agreements, and later their implementation, an incompatibility of both parties' interests occurs. The client's goal and interest is the completion of an IT project within the planned time frame and budget, considering the Total Cost of Ownership (TCO) and meeting all the organizational and technological requirements designed for the project. The supplier's goal and interest lies in achieving a planned income in the whole life cycle of the project, meeting the planned quality of completed work. Table I (Source: Own Study) presents the contradictions between the client's and supplier's interest in case of completing an IT project consisting in the implementation of a management support information system.

Y. Lichtenstein [8] points out that a high level of information asymmetry between the supplier-agent and the client-principal means that at every stage of the project's life cycle, the supplier-agent may be prone to the abuse of trust: moral hazard, which results directly from the high level of information asymmetry concerning both the ERP, CRM, DMS and BI-class software as such, and the method of implementing the project. Especially in the case of projects completed on the basis of a fixed budget, the supplier-agent may have a strong motivation to push the cost below the planned budget, which can have an influence on the quality of services. ${ }^{3}$

\footnotetext{
${ }^{3}$ The research was carried out in 2013 . It covered 500 enterprises where 895 IT projects consisting in the implementation of ERP, CRM, BI, DMS, $\mathrm{BI}$ and E-learning-class management support information systems were completed. The chosen enterprises were based in Mazovia and Lesser Poland and the research was conducted among enterprises employing less than 400 people. Research results showed that in the management support information system market in Poland, the structure of agreement types is as follows: $68 \%$ - fixed price contract, $27 \%$ - time and material contract, $5 \%$ - cost-reimbursable contracts.
} 
TABLE I.

GOALS AND INTERESTS OF BOTH TRANSACTION PARTIES

\begin{tabular}{|l|}
\hline \multicolumn{1}{|c}{ Client's goals and interests } \\
\hline Fulfilling business goals \\
Fulfilling technological goals \\
Completing the project within the time frame \\
Completing the project within the maximum planned budget \\
Minimizing the total cost of software ownership (TCO) \\
Achieving functional and technological solutions creating a \\
temporary competitive edge
\end{tabular}

The supplier-agent possesses all the information about their current activities and all their plans linked to project completion, while the client-principal has only a limited knowledge in this area. Knowledge concerning the completion of IT projects consisting in the implementation of management support information systems is increasingly robust and dynamically changing, which means that the client-principal is not able to effectively negotiate a favorable contract, and then supervise this type of project on their own. Due to the fact that both parties' interests are not equal, the supplier-agent may be prompted to take inappropriate action, i.e. abuse trust (moral hazard), in a situation where they are not controlled because the knowledge and experience of the client-principal limit the possibilities of effective control. The potential action of the supplier-agent aimed at securing the realization of their particular interests may result from their opportunism. Inappropriate behavior of the supplier-agent manifesting itself in trust abuse in the second stage, which is completed on the basis of a fixed budget, and in the third stage of a project's life cycle may lead to:

A. Guaranteeing full project profitability for the supplier-agent when it turns out that, already after signing the implementation agreement, the scope of the project is larger than originally foreseen at the bidding stage. This situation may occur when the client-principal was only guided by the price in their choices, while the competition amongst the suppliers was high. In the current situation of hypercompetition on the market, it may happen that this type of projects may be offered at a lowered price. In this situation, paradoxically, it is the client-principal who should make sure that the project price is not too low, with the assumption that they have given the supplieragent all the requirements for the implemented IT system.

$B$. Increasing project profitability for the supplier-agent compared to the earlier plan of completing the project at a lower cost.

The result of the supplier-agent's trust abuse in the project's whole life cycle may be the occurrence of one, or a combination of several organizational complications impacting the effectiveness of an IT project, i.e.:
1. Lack of complete or partial fulfillment of project goals.

2. Unjustified exceeding of the budget in the completion of the second stage, as well as the third stage, the socalled Total Cost of Ownership.

3. Unjustified exceeding of the planned time frame for the completion of the second stage.

An important organizational aspect of the contract between the supplier-agent and the client-principal is an attempt to construct a mechanism which would effectively eliminate the possibility of trust abuse in the second and third stage of the project life cycle. Designing such a mechanism may turn out to be costly and difficult to complete [4]. My research results will allow us to indicate and describe selected attempts to abuse trust by the supplier-agent in IT projects consisting in the implementation of management support information projects, i.e. ERP, CRM, BI, and DMS.

\section{RESEARCH METHODOLOGY}

In my research, I have used the multiple case study method. Four enterprises which implemented and are currently using management support information systems, i.e. ERP, CRM and DMS, constituted the subject of research. The goal of the case study is developing the agency theory, and especially a better understanding of the notion of moral hazard in management support information systems.

I analyze the case study, as it allows us to develop the existing theory and provide explanations of phenomena unrecognized before, such as moral hazard in IT projects. I focus on the client's perspective during the whole life cycle of an IT project in an enterprise, i.e. from the bidding stage to the operation of management support information systems. My choice of research method - case study, is motivated chiefly by two circumstances [9]:

1. The early stage of knowledge development in the given research area, i.e. agency theory in a specific group of IT projects.

2. Lack of recognition of moral hazard in real conditions.

As part of the multiple case study analysis, I would like to pose the following research question: 
In what behaviors does moral hazard in the relation between the principal (client) and the agent (supplier) manifest itself in case of IT projects consisting in the implementation of management support information systems based on outsourcing?

The choice of studied cases was carried out through purposive sampling. According to B. Flyvbjerg [10], there are five main criteria of case selection. Table II (Source: [10]) presents the criteria along with their characteristics in the context of conducted research.

TABLE II.

FIVE MAIN CRITERIA OF CASE SELECTION

\begin{tabular}{|l|l|}
\hline \multicolumn{1}{|c|}{ Criterium } & \multicolumn{1}{c|}{\begin{tabular}{c}
\multicolumn{1}{c|}{ Information on the fulfillment of the } \\
criteria
\end{tabular}} \\
\hline \multicolumn{1}{|c|}{ Data availability } & \multicolumn{1}{c|}{ Guaranteed } \\
\hline $\begin{array}{l}\text { Distinctiveness of the } \\
\text { case, clearly illustrating } \\
\text { studied patterns }\end{array}$ & $\begin{array}{l}\text { Projects that ended in partial failure, but } \\
\text { not interrupted during the implementation }\end{array}$ \\
\hline $\begin{array}{l}\text { Variation in the } \\
\text { analyzed cases }\end{array}$ & $\begin{array}{l}\text { Variation in the analyzed cases is } \\
\text { expressed in the selection of: } \\
\text { - IT projects consisting in the } \\
\text { implementation of four management } \\
\text { support information systems, i.e. ERP, } \\
\text { CRM, DMS } \\
\text { - Client profile } \\
\text { - The results of project implementation }\end{array}$ \\
\hline $\begin{array}{l}\text { Critical character of the } \\
\text { phenomenon allowing } \\
\text { to formulate a general } \\
\text { statement }\end{array}$ & $\begin{array}{l}\text { The incidence of moral hazard between } \\
\text { the agent (supplier) and the principal } \\
\text { (client) during the whole life cycle of } \\
\text { project implementation influences the } \\
\text { results of project implementation from the } \\
\text { client's perspective. }\end{array}$ \\
\hline $\begin{array}{l}\text { Metaphor allowing to } \\
\text { point the researcher's } \\
\text { attention towards a } \\
\text { specific course of the } \\
\text { studied phenomenon }\end{array}$ & $\begin{array}{l}\text { Aiming to analyze the phenomenon of } \\
\text { moral hazard in the entire project life } \\
\text { cycle, I selected cases that could be } \\
\text { studied at the stages of: bidding, contract } \\
\text { negotiations, implementation and } \\
\text { information system operation. }\end{array}$ \\
\hline
\end{tabular}

\section{RESEARCH RESULTS AND THEIR INTERPRETATION}

Table III (Source: Own Study) presents the results of multiple case study research.

I analyzed the implementation of ERP, CRM, BI and DMS-class management support information systems completed as part of a contract based on a fixed budget. All the analyzed implementation projects ended in partial failure, although their implementation was not interrupted. I diagnosed three major types of supplier's behavior, through which moral hazard, resulting from the opportun- ism $^{4}$ of the supplier-agent and a high level of information asymmetry between the client (principal) and the supplier (agent) in IT projects, manifested itself.

Behavior 1. An attempt to minimize the supplier's cost of completing stage 2 and 3 of the project by:

- Engaging specialists with low competences and little experience, which is linked to their low salary.

- Lowering the actual workload of consultants working on specific tasks in the project in comparison to the workload declared in the agreement regulating the outsourcing of implementation services.

Behavior 2. An attempt to sell implementation services concerning stage 2 at a lowered price, which will allow them to win the tender in the conditions of hypercompetition in the market. The supplier's intention is to compensate for the possible losses in stage 2 with profits in stage 3.

Behavior 3. An attempt to intentionally complete chosen types of project tasks in stage 2 poorly, e.g. acceptance tests, training and project documentation in order to create a competence gap concerning system configuration amongst client's application users and make it impossible for them to introduce changes to the configuration independently, e.g. in stage 3 , which will increase the number of client's orders from the supplier.

To sum up, in their entire life cycles, the analyzed projects did not end in full project success, however we need to stress that the projects were not interrupted and abandoned. Two main results of project complications were observed, i.e. exceeding the budget both in stage 2 and 3 , and exceeding the time frame without justification while completing stage 2 . In each case, the clients engaged external consultants, who in the first two stages of the project played the part of the "client's advocate", indicating the dangers linked to the supplier's behavior and the possible consequences of their materialization. Another role of the external consultants was suggesting counteractions to the client, in order to minimize the danger of the project ending in a total failure. Most probably, it was the engagement of external consultants that led to the projects' partial success and prevented them from failing completely. In spite of this, the respondents from the client's side clearly indicated that the supplier's behavior, through which the moral hazard manifested itself, was the source of project complications. Amongst the researched IT projects, there were three types of behavior that demonstrated moral hazard on the supplier-agent's side. In-depth analytical workshops with the representatives of the client-principal showed that the members of client's project group diagnosed the described behavior already

4 Polish Language Dictionary (Warszawa: PWN, 1996), defines opportunism as concentrating on one's personal interest while ignoring common goals and generally assumed codes of behavior. 
during stage 2 of the project. Moral hazard at this stage of the IT project leads to a deep crisis of trust and decreases the chances of a successful project completion. The mutual loss of trust influences the increase of transaction costs [11], especially the cost of monitoring the agreement implementation, the adjustment cost and the cost of terminating the agreement by the client, which can on its own lead to a complete failure of the project. In analyzed cases, increasing client's transaction costs was visible mostly in the increasing workload of the tasks. During indepth workshops, the respondents on the client's side made suggestions that they would like to pass on to the future client's project managers, who will be responsible for the implementation of stages 1 and 2 of the IT projects:

- Engaging external consultants as client's "advocates" with the aim to support the completion of stages 1 and 2 .

- Professional preparation for project implementation by the workers from client's project group:

o Specifying precisely (ex ante) the functional requirements of the system.

o Specifying precisely (ex ante) the direct and indirect benefits of the project.

o Specifying precisely (ex ante) the requirements for the supplier.

o Specifying precisely (ex ante) the requirements for the IT system.

- Designing an implementation agreement, which could eliminate the morally hazardous behavior of the supplier.

We need to stress here that the presented types of supplier's behavior are universal and they concern all the relations between the supplier and the client, also in case of contracts signed in public administration.

\section{CONCLUSIONS}

The respondents stressed that the agreements of software licensing purchase, service purchase and Service Level Agreement are not simple and even in the current economic structure there are very few specialized lawyers who, linking their legal and MIS knowledge, could secure the company's interests. During in-depth analytical workshops, the respondents indicated that many lawyers de-

TABLE III.

THE RESULTS OF MULTIPLE CASE STUDY RESEARCH

\begin{tabular}{|c|c|c|c|c|}
\hline & Company $\mathbf{X}$ & Company Y & Company $\mathbf{Z}$ & Company A \\
\hline $\begin{array}{l}\text { Client's (principal's) } \\
\text { profile }\end{array}$ & Bank & Manufacturing company & Service company & Legal firm \\
\hline $\begin{array}{l}\text { Type of purchased IT } \\
\text { system }\end{array}$ & $\mathrm{BI}$ & ERP & CRM & DMS \\
\hline $\begin{array}{l}\text { Supplier's (agent's) } \\
\text { profile }\end{array}$ & $\begin{array}{l}\text { Reseller of software } \\
\text { designed by the } \\
\text { market leader }\end{array}$ & $\begin{array}{l}\text { Reseller of software } \\
\text { designed by the market } \\
\text { leader }\end{array}$ & $\begin{array}{l}\text { Reseller of software } \\
\text { designed by the market } \\
\text { leader }\end{array}$ & $\begin{array}{l}\text { Reseller of software } \\
\text { designed by the market } \\
\text { leader }\end{array}$ \\
\hline System operation period & 5 years & 4 years & 7 years & 7 years \\
\hline Implementation results & $\begin{array}{l}\text { Project not completed } \\
\text { on time without } \\
\text { justification, stage } 2 \\
\text { completed within the } \\
\text { budget, operational } \\
\text { costs increased } \\
\text { significantly in stage } 3 \\
\text { compared to the } \\
\text { original estimate, not } \\
\text { all the business goals } \\
\text { completed. }\end{array}$ & $\begin{array}{l}\text { Project not completed on } \\
\text { time without justification, } \\
\text { stage } 2 \text { not completed } \\
\text { within the budget, } \\
\text { operational costs increased } \\
\text { significantly in stage } 3 \text {, not } \\
\text { all the business goals } \\
\text { completed. }\end{array}$ & $\begin{array}{l}\text { Project not completed } \\
\text { on time without } \\
\text { justification, stage } 2 \text { not } \\
\text { completed within the } \\
\text { budget, operational } \\
\text { costs in stage } 3 \\
\text { according to the plan, all } \\
\text { the business goals } \\
\text { completed. }\end{array}$ & $\begin{array}{l}\text { Project not completed } \\
\text { on time without } \\
\text { justification, completed } \\
\text { within the budget, not } \\
\text { all the business goals } \\
\text { completed. }\end{array}$ \\
\hline $\begin{array}{l}\text { Type of implementation } \\
\text { services }\end{array}$ & Fixed budget & Fixed budget & Fixed budget & Fixed budget \\
\hline $\begin{array}{l}\text { How does the moral } \\
\text { hazard in the principal } \\
\text { (client) - agent (supplier) } \\
\text { relation manifest? }\end{array}$ & $\begin{array}{l}\text { The budget for the } \\
\text { completion of stage } 2 \\
\text { was calculated by the } \\
\text { supplier on the basis } \\
\text { of a lower hourly } \\
\text { wage for the } \\
\text { consultant than } \\
\text { stipulated by the } \\
\text { maintenance service } \\
\text { budget in the SLA } \\
\text { agreement regulating } \\
\text { the system } \\
\text { maintenance services } \\
\text { in stage } 3 \text {, i.e. the } \\
\text { operation stage. The } \\
\text { change of rates took } \\
\text { place directly after the } \\
\text { completion of stage } 2 . \\
\text { Thus, the total system } \\
\text { maintenance cost } \\
\text { (TCO) increased in } \\
\text { relation to the } \\
\text { estimates completed } \\
\text { in stage } 1 .\end{array}$ & $\begin{array}{l}\text { Engaging people with low } \\
\text { qualifications and little } \\
\text { professional experience in } \\
\text { the area of a specific ERP } \\
\text { system in the given } \\
\text { manufacturing company. } \\
\text { Thus, the client does not } \\
\text { obtain the benefits resulting } \\
\text { from the knowledge transfer } \\
\text { and good practice. } \\
\text { Decreasing the engagement } \\
\text { of supplier's consultants in } \\
\text { some implementation tasks, } \\
\text { e.g. completing acceptance } \\
\text { testing with system } \\
\text { calibration in comparison to } \\
\text { the obligations included in } \\
\text { the agreement concerning } \\
\text { the workload of this task. }\end{array}$ & $\begin{array}{l}\text { The low quality of } \\
\text { knowledge transfer } \\
\text { carried out by the } \\
\text { supplier, both regarding } \\
\text { the configuration and } \\
\text { operation of the system } \\
\text { by its end users, with the } \\
\text { aim of creating the } \\
\text { client's competence } \\
\text { gap. } \\
\text { The supplier's } \\
\text { consultant-programmer } \\
\text { programs the system to } \\
\text { limit the workload } \\
\text { during the completion of } \\
\text { stage } 2 \text {, e.g. by } \\
\text { introducing constants } \\
\text { instead of variables in } \\
\text { the code, which results } \\
\text { in eliminating the } \\
\text { possibility of } \\
\text { configuring a given } \\
\text { function simply and } \\
\text { without an excessive } \\
\text { workload in stage } 3 \text {. }\end{array}$ & $\begin{array}{l}\text { Engaging people with } \\
\text { low qualifications and } \\
\text { little professional } \\
\text { experience in the area } \\
\text { of a specific CRM } \\
\text { system implementation. } \\
\text { The people engaged by } \\
\text { the supplier as key } \\
\text { consultants had only } \\
\text { graduated from } \\
\text { university 2-3 years } \\
\text { beforehand. Decreasing } \\
\text { the engagement of the } \\
\text { supplier's consultant in } \\
\text { certain implementation } \\
\text { tasks (e.g. ensuring the } \\
\text { quality of data migrated } \\
\text { from the old system to } \\
\text { the new system, } \\
\text { training key system } \\
\text { users) in comparison to } \\
\text { the obligations included } \\
\text { in the agreement } \\
\text { regarding the workload } \\
\text { of the task. }\end{array}$ \\
\hline
\end{tabular}


signed the agreements trying to eliminate the moral hazard, struggling between two extreme approaches, i.e. case-specific agreement, which was supposed to foresee and eliminate the majority of dangers resulting from cooperation in stage 2 and 3 , and a simplified agreement regulating only the basic aspects of the cooperation. In case of case-specific agreements, transaction costs increase dramatically ${ }^{5}$. The presented research results point towards three basic behaviors of the supplier where moral hazard occurred in IT projects, resulting from the opportunism of the supplieragent and a high level of information asymmetry between the client (principal) and the supplier (agent). All the three types of behaviors increased the risk of an unsuccessful IT project implementation and influenced the transaction costs, also through the loss of mutual trust. Identifying the unwanted behavior of the supplier allowed the client's project group to react and to minimize the risk of the project's failure.

New institutional economy treats enterprises as a cluster of contracts and it makes the success of the projects dependent on the quality of agreements. We need to underline that institutional economy focuses not only on analyzing the available choices and making those choices, but also on solving conflicts as part of the enterprise's stream of contracts. Considering the current and projected saturation of the market with management support information systems, we need to stress that a cluster of contracts regulating IT outsourcing constitutes one of the most important agreement groups in a large group of enterprises. Until now, IT projects were rarely analyzed from the perspective of institutional economy by Polish theoreticians of business informatics, thus creating a research gap. Special attention in this area is owed to the work by J. Auksztol [3]. I believe that tightening the knowledge gap and promoting the knowledge, as well as practical skills in this area, may increase the effectiveness of implementing IT projects based on outsourcing, both in enterprises and government agencies.

\section{REFERENCES}

[1] J. N. Lee, S. M. Miranda, Y. M. Kim, "IT outsourcing strategies: universalistic, contingency, and configurational explanations of success," Information Systems Research, vol. 15, no. 2, pp. 110-131, 2004.

[2] J. Dibbern, T. Goles, R. Hirscheim, B. Jayatilaka, "Information systems outsourcing: a survey and analysis of the literature," The Data Base for Advance in Information Systems, vol. 35, no. 4, pp. 6-102, 2004.

[3] J. Auksztol, IT Outsourcing in Management, Theory and Practice (Outsourcing Informatyczny $w$ Teorii $i$ Praktyce Zarzqdzania). Gdańsk: University of Gdańsk Press, 2008, pp. 50-51.

[4] K. M. Eisenhardt, "Agency theory: an assessment and review," Academy of Management Review, vol. 14, no.1, pp. 57-74, 1989.

[5] A. E. Dembe and L. I. Boden,"Moral hazard: a question of morality?," New Solutions, vol. 10, no. 3, pp. 257-279, 2000.

[6] T. Gruszecki, Modern Enterprise Theories (Wspótczesne Teorie Przedsiębiorstwa). Warszawa: PWN, 2002, p. 193.

[7] J. M. Buchanan, "A contractarian paradigm for applying economic theory," The American Economic Review, vol. 65, no. 2, pp. 225-230, 1975.

[8] Y. Lichtenstein, "Puzzles in software development contracting," Communications of the ACM, vol. 47, no. 2, pp. 61-65, 2004.

[9] R. Yin, Case Study Research: Design and Methods. Thousand Oaks, CA: Sage Publications, 1984.

[10] B. Flyvbjerg, "Five misunderstandings about case-study research," in Qualitative Research Practice, C. Seale, G. Gobo, J. F. Gubrium, D. Silverman, Eds. London-Thousand Oaks: Sage Publications, 2004.

[11] O. E. Williamson, "Market and hierarchies: some elementary considerations," The American Economy Review, vol. 61, no. 2, pp. 112-123, 1971.

\footnotetext{
${ }^{5}$ In one of the analyzed cases, the case-specific implementation services agreement for stage 2 was over 300 pages long, it was negotiated for 4 months, while the implementation project lasted 3 months and did not exceed 50000 PLN.
} 